ISSN 0258-7122

Bangladesh J. Agril. Res. 38(4): 613-623, December 2013

\title{
YIELD PERFORMANCE OF OYSTER MUSHROOM (Pleurotus ostreatus) ON DIFFERENT SUBSTRATES
}

\author{
D. DAS ${ }^{1}$, M. KADIRUZZAMAN ${ }^{2}$, S. K. ADHIKARY ${ }^{3}$ \\ M.Y. KABIR ${ }^{4}$ AND M. AKHTARUZZAMAN ${ }^{5}$
}

\begin{abstract}
An experiment was conducted at Mushroom Lab of Horticulture Centre under Department of Agricultural Extension (DAE), Khairtala, Jessore to determine the performance of different substrates on the yield of oyster mushroom (Pleurotus ostreatus). Sugarcane bagasse, sawdust, and coconut coir individually and their combinations were used as substrates. The experiment was laid out in Completely Randomized Design (CRD) with five replications. Data were taken from $1^{\text {st }}$ and $2^{\text {nd }}$ flush of different growth and yield attributes of mushroom. The maximum number of effective fruiting bodies was obtained from sawdust (40) and the lowest number (31.6) from combination of sawdust and coconut coir $(1: 1)$. In the $1^{\text {st }}$ flush, the maximum weight of individual fruiting body was observed in coconut coir and minimum in sawdust. The highest biological (186.06 g) and economic yield (180.64 g) were obtained from coconut coir and the lowest from sugarcane bagasse. The maximum and minimum harvest index was found in $1^{\text {st }}$ flush at coconut coir and combination of sawdust and sugarcane bagasse (1:1), respectively. Most yield attributes were found higher in coconut coir. Economic yield was positively correlated to number of effective fruiting bodies, pileus diameter, and biological yield.
\end{abstract}

Keywords: Pleurotus ostreatus, sugarcane bagasse, coconut coir, saw dust, mushroom, and yield.

\section{Introduction}

Pleurotus ostreatus is one of the most popular oyster mushroom species that can grow on different agricultural wastes. Lignin and cellulose containing materials, such as sawdust, coconut coir, sugarcane bagasse, wheat straw, and rice straw are widely used for oyster mushroom production (Yildiz and Ertekin, 1996). Substrate supplies nutrients for growth and development of fruiting body of mushroom (Chang and Miles, 1988). Pleurotus (oyster mushroom) can use the largest variety of wastes for its fast mycelial growth by its multilateral

\footnotetext{
${ }^{1}$ Lecturer, Agrotechnology Discipline, Khulna University (KU), Khulna, ${ }^{2}$ Student, Agrotechnology Discipline, KU, Khulna, ${ }^{3}$ Professor, KU, Khulna, ${ }^{4}$ Associate Professor, KU, Khulna, ${ }^{5}$ Quarantine Entomologist, Department of Agricultural Extension (DAE), Khamarbari, Dhaka, Bangladesh.
} 
enzymes (Poppe, 2000). Sawdust, sugarcane bagasse, and coconut coir are mainly composed of cellulose, hemicellulose, lignin. Pleurotus ostreatus grows well in sawdust, sugarcane bagasse, and coconut coir. In Bangladesh, these materials are in abundance which is not being well industrialized and farmers dispose them by burning. These agricultural wastes may offer opportunity for mushroom production, which may be economically viable and environment friendly. If these materials can be used for oyster mushroom cultivation, then these materials may serve as a cheap source of substrate for mushroom growers. Various supplements can be added to the substrates to improve growth and yield of mushroom (Hadwan et al., 1997). So, the experiment was conducted using sawdust, sugarcane bagasse, and coconut coir at various compositions with a view to determining a suitable substrate for production of Pleurotus ostreatus.

\section{Materials and Method}

The experiment was conducted at Mushroom Lab of Horticulture Centre under Department of Agricultural Extension (DAE), Khairtala, Jessore during the period of 30 October 2008 to 30 February 2009 to determine yield performance of oyster mushroom (Pleurotus ostreatus) on different substrates.

\section{Preparation of pure culture}

Twelve days old culture of juvenile tissue of mushroom in test tube containing PDA medium is known as pure culture. To obtain pure culture a small piece of juvenile tissue taken from the fruiting body was placed into the PDA medium under aseptic condition.

\section{Preparation of PDA medium}

The PDA medium was prepared by mixing extracts of 250 g peeled and sliced potato, $20 \mathrm{~g}$ glucose, $30 \mathrm{~g}$ agar in $1000 \mathrm{ml}$ distilled water. The medium was supplemented with $250 \mathrm{mg}$ of asparagines.

\section{Mother culture}

Mother culture was prepared by using wheat grain. Wheat grains were soaked in water for 12-14 hours and then boiled. After draining out of excess water, calcium carbonate $(1 \mathrm{~g} / 100 \mathrm{~g})$ was added manually. The moisture level of the

mixture was maintained about $65 \%$ by adding tap water. Each polypropylene bag 
of $80 \times 25 \mathrm{~cm}$ size was filled with $250 \mathrm{~g}$ of prepared mixture and packed tightly. The neck of the bag was prepared by heat resistant polyvinyl chloride (PVC) tube. A hole of about $3 \mathrm{~cm}$ was made with glass rod at the centre of the mouth to put the inoculums. A piece of pure culture $\left(1.0 \mathrm{~cm}^{2}\right)$ was placed aseptically into the mouth. All the packets were plugged with cotton and covered with brown paper. Then the inoculated packets were placed in growth chamber at $25 \pm 1^{\circ} \mathrm{C}$ in dark. After 18 to 20 days, mother culture became white due to complete colonization of mycelium running. The fully colonized packets were used for spawning.

\section{Culture of spawn packet}

After completion of mycelium run in the spawn packet, brown paper, and rubber band of spawn packets were removed from the mouth. Then the mouth of spawn packet was wrapped tightly with rubber band. Two opposite sides of the upper position of spawn packet were opened as D-shape with a blade by removing the plastic sheet. After that the opened surface was scrubbed slightly to remove the thin whitish mycelia layer. Then spawn packets were soaked in water for 10-15 minutes. Water was sprinkled twice a day on the cut surface of spawn packet to maintain $80-85 \%$ relative humidity until the mushroom were matured enough to be harvested.

Treatments: Six substrates were used as treatments in this experiment viz., $\mathrm{T}_{1^{-}}$ sugarcane bagasse, $\mathrm{T}_{2}$-coconut coir, $\mathrm{T}_{3}$-sawdust, $\mathrm{T}_{4^{-}}$sugarcane bagasse and coconut coir (1:1), $\mathrm{T}_{5}$-sugarcane bagasse and sawdust (1:1), $\mathrm{T}_{6^{-}}$sawdust and coconut coir (1:1). Wheat bran (10\%) was used as supplement in each treatment.

Data collection: The data of following parameters were collected manually on mycelium running rate in spawn packet ( $\mathrm{cm} /$ day), time required to complete mycelium running in spawn packet (day), stalk diameter $(\mathrm{cm})$, stalk length $(\mathrm{cm})$, pileus diameter $(\mathrm{cm})$, pileus thickness $(\mathrm{cm})$, weight of individual fruiting bodies (g), number of effective fruiting body, biological yield (g), economic yield (g), harvest index (\%).

Statistical analysis: The collected data were analyzed for partitioning the total variance using computer operated MSTAT-C programme. The treatment means were compared by Duncan's Multiple Range Test (Gomez and Gomez, 1984). Functional relationships were determined among different yield and growth parameters using simple regression analysis. 


\section{Results and Discussion}

\section{Mycelium running rate}

Mycelium running rate in spawn packet was ranged from 0.39 to $0.53 \mathrm{~cm}$ per day $^{1}$. The highest mycelium running rate was observed from saw dust and the lowest mycelium running rate was found in sugarcane bagasse (Table1). The presence of right proportion of alphacellulose, hemicellulose, and lignin was the probable cause of higher rate of mycelium running in substrate. The lowest mycelium running rate might be due to presence of different kinds of polyphenolic substances in them as suggested by Wang (1982) and low content of cellulose (Gohl, 1993). The capacity of mushroom to grow on lingo-cellulosic substrates is related to the vigor of its mycelium (Permana et al., 2004).

Days required for completion of mycelium running: Days required for completing mycelium running in spawn packet ranged from 23.4 to 30.8 days on different substrates. The lowest days required to complete mycelium running was recorded from saw dust and highest days required to complete mycelium running was found from the combination of sugarcane bagasse and sawdust (1:1) (Table 1). The appreciable days to complete mycelium running of oyster mushroom on different substrates might be due to variation in their chemical composition and C: N ratio as reported by Bhatti et al. (1987).

Table1. Effect of different substrates on mycelial growth of oyster mushroom.

\begin{tabular}{l|l|l}
\hline \multicolumn{1}{c|}{ Substrates } & \multicolumn{1}{c|}{$\begin{array}{c}\text { Mycelium running } \\
\text { rate in spawn packet } \\
\text { (cm/day) }\end{array}$} & $\begin{array}{c}\text { Days required for } \\
\text { completion of } \\
\text { mycelium } \\
\text { running }\end{array}$ \\
\hline Sugarcane bagasse & $0.39 \mathrm{~d}$ & $26.00 \mathrm{bc}$ \\
Coconut coir & $0.46 \mathrm{bc}$ & $29.60 \mathrm{a}$ \\
Sawdust & $0.53 \mathrm{a}$ & $23.40 \mathrm{c}$ \\
Sugarcane bagasse and coco nut coir (1:1). & $0.47 \mathrm{~b}$ & $28.40 \mathrm{ab}$ \\
Sugarcane bagasse and sawdust $(1: 1)$ & $0.40 \mathrm{~d}$ & $30.80 \mathrm{a}$ \\
Sawdust and coconut coir (1:1) & $0.45 \mathrm{c}$ & $29.60 \mathrm{a}$ \\
\hline CV (\%) & 6.04 & 5.82 \\
Level of significant) & $* *$ & $* *$ \\
\hline
\end{tabular}

** = Significant at $1 \%$ level. 


\section{Stalk length}

The stalk length of fruiting body of different substrates ranged from 3.22 to 4.12 $\mathrm{cm}$ and 3.27 to $4.66 \mathrm{~cm}$ in $1^{\text {st }}$ and $2^{\text {nd }}$ flush, respectively. In $1^{\text {st }}$ flush, the lowest stalk length was obtained from sugarcane bagasse and highest stalk length was found from combination of sugarcane bagasse and coconut coir (1:1). In $2^{\text {nd }}$ flush, the lowest stalk length was found from coconut coir. In $2^{\text {nd }}$ flush, the highest stalk length was found from combination of sawdust and coconut coir (1:1) (Table 2). Kurtzman and Zadrazil (1982) reported that the elongation of stalk resulting the reduction of pileus diameter and pileus thickness which might be due to the fact that nutrients of substrates become exhausted to elongate the stalk which lead to reduce of pileus diameter and pileus thickness.

\section{Stalk diameter}

The stalk diameter of fruiting body of different substrates ranged from 0.78 to $0.87 \mathrm{~cm}$ and 0.68 to $0.74 \mathrm{~cm}$ in $1^{\text {st }}$ and $2^{\text {nd }}$ flush, respectively. In $1^{\text {st }}$ flush, the minimum stalk diameter was obtained from combination of sugarcane bagasse and coconut coir (1:1) and the maximum stalk diameter was recorded from combination of sugarcane bagasse and sawdust (1:1). In case of $2^{\text {nd }}$ flush, the highest stalk diameter was found from combination of sugarcane bagasse and coconut coir (1:1) and minimum was recorded from combination of sugarcane bagasse and saw dust (Table 2).

\section{Pileus diameter}

The pileus diameter ranged from 7.02 to $8.28 \mathrm{~cm}$ and 6.52 to $8.43 \mathrm{~cm}$ in $1^{\text {st }}$ flush and $2^{\text {nd }}$ flush, respectively. The maximum pileus diameter was obtained from combination of sawdust and coconut coir and minimum was recorded from coconut coir in $1^{\text {st }}$ flush. In case of $2^{\text {nd }}$ flush, the peak pileus diameter was obtained from combination of sawdust and sugarcane bagasse (1:1). In $2^{\text {nd }}$ flush, the lowest pileus diameter was recorded from sugarcane bagasse (Table 2). High $\mathrm{C}: \mathrm{N}$ ratio is very important for pileus diameter and pileus thickness. It is likely that sawdust has a high $\mathrm{C}: \mathrm{N}$ ratio which resulted in the enhanced growth of the pileus (Veena et al., 1998)

\section{Pileus thickness}

The pileus thickness ranged from 0.44 to $0.48 \mathrm{~cm}$ and 0.49 to $0.58 \mathrm{~cm}$ in $1^{\text {st }}$ flush and $2^{\text {nd }}$ flush, respectively. The maximum pileus thickness was observed from 
combination of sawdust and sugarcane bagasse (1:1) and lowest was observed in sawdust in $1^{\text {st }}$ flush. In $2^{\text {nd }}$ flush, the maximum pileus thickness was found from combination of sawdust and coconut coir (1:1). The lowest pileus thickness was obtained from coconut coir (Table 2).

\section{Number of effective fruiting bodies}

The number of effective fruiting bodies ranged from 31.6 to 40 and 16.6 to 27.2 in $1^{\text {st }}$ and $2^{\text {nd }}$ flush, respectively. In $1^{\text {st }}$ flush, the maximum number of fruiting bodies was observed in sawdust and minimum number of fruiting bodies was observed in combination of sawdust and coconut coir (1:1) (Table 2 ). The variation of number of effective fruiting bodies might be due to passing of time as nutrient concentration decreased in spawn packet gradually. Yoshida et al. (1993) reported that number of effective fruiting bodies might be increased when substrates were mixed with wheat bran as supplements.

\section{Weight of individual fruiting body}

Weight of individual fruiting body is an indication of yield. In $1^{\text {st }}$ flush, the maximum weight of individual fruiting body was observed in coconut coir and minimum weight of individual fruiting body was found at sawdust. In $2^{\text {nd }}$ flush, the highest average individual weight of fruiting body was obtained in combination of coconut coir and sugarcane bagasse (1:1) and lowest was found from sawdust (Fig. 1).

\section{Biological yield}

Biological yield of oyster mushroom on different substrates ranged from 89 to $131 \mathrm{~g}$ and 49.2 to $61.28 \mathrm{~g}$ per $500 \mathrm{~g}$ spawn packet in $1^{\text {st }}$ and $2^{\text {nd }}$ flush, respectively. The highest biological yield was obtained from coconut coir and lowest from sawdust in $1^{\text {st }}$ flush. In case of $2^{\text {nd }}$ flush, the maximum biological yield was obtained from the combination of sawdust and coconut coir (1:1) (Table 3). The minimum biological yield was obtained in sugarcane bagasse in $2^{\text {nd }}$ flush. The higher biological yield was obtained in $1^{\text {st }}$ flush than $2^{\text {nd }}$ flush due to high nutrient content in spawn packet at initial period. The cellulose and hemicellulose of substrates are reduced by passing of time after inoculation (Adamovic et al., 1996) which might be the possible cause of lower number of fruiting bodies and yield is in latter flushes. 


\section{Economic yield}

The economic yield ranged from 85.94 to $127.74 \mathrm{~g}$ and 47.02 to $58.18 \mathrm{~g}$ per 500 g spawn packet in $1^{\text {st }}$ flush and $2^{\text {nd }}$ flush, respectively. The maximum economic yield was obtained from coconut coir and minimum from combination of sugarcane bagasse and coconut coir (1:1) in $1^{\text {st }}$ flush. In $2^{\text {nd }}$ flush, the utmost economic yield was found from the combination of sugarcane bagasse and sawdust (1:1) and the minimum economic yield was found from sugarcane bagasse (1:1) (Table 3). From the result, it can be concluded that performance of coconut coir is better than other substrates due to yield response. In most substrates, higher yield was obtained in $1^{\text {st }}$ flush than that of $2^{\text {nd }}$ flush. Substrates rich in usable nitrogen after spawn run bring about enhancing the mushroom yield and quality and in bioconversion and bioaccumulation efficiency (Patil et al., 2008)

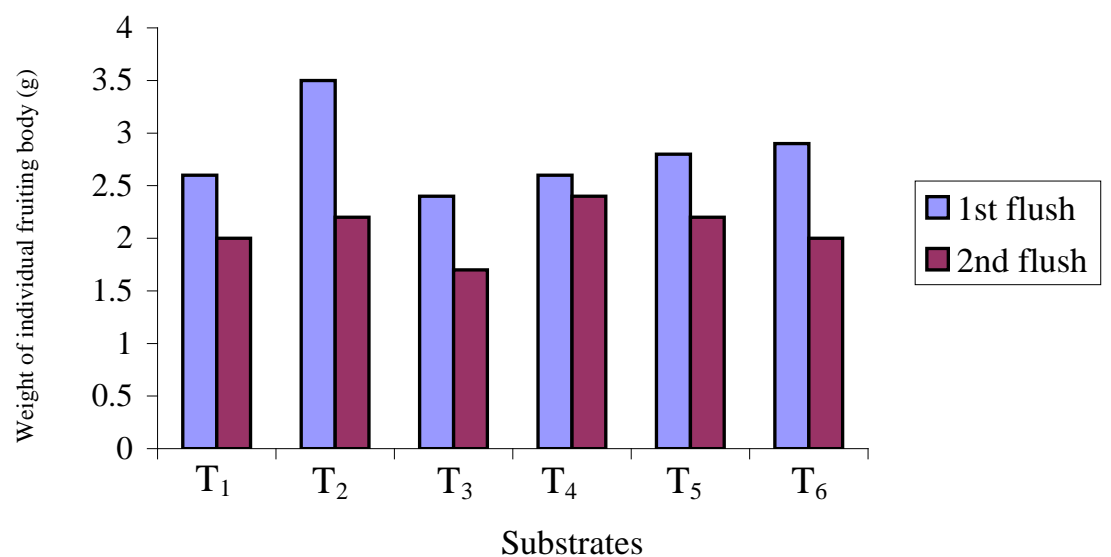

Fig. 1. Performance of different substrates on weight of individual fruiting body.

** $\mathrm{T}_{1}$ - sugarcane bagasse, $\mathrm{T}_{2}$-coconut coir, $\mathrm{T}_{3}$-sawdust, $\mathrm{T}_{4}$ - sugarcane bagasse and coconut coir (1:1), $\mathrm{T}_{5}$-sugarcane bagasse and sawdust (1:1), $\mathrm{T}_{6}$ - sawdust and coconut coir (1:1).

\section{Harvest index}

Harvest index is a ratio of economical yield to biological yield which indicates the suitability of substrates. The range of harvest index is $96.12-97.51 \%$ and $94.19-96.26 \%$ in $1^{\text {st }}$ flush and 2nd flush, respectively. There is no significant difference in harvest index among different substrates but maximum harvest index (97.51\%) was observed from coconut coir and minimum harvest index (96.12\%) was recorded from combination of sawdust and sugarcane bagasse (1:1) in $1^{\text {st }}$ flush (Table 3). In case of $2^{\text {nd }}$ flush, the maximum harvest index was obtained from the combination of sugarcane bagasse and sawdust (1:1) and minimum was found from coconut coir. 
Table 2. Performance of different substrates on yield attributes of oyster mushroom.

\begin{tabular}{|c|c|c|c|c|c|c|c|c|c|c|}
\hline \multirow{2}{*}{ Substrates } & \multicolumn{2}{|c|}{ Pileus diameter $(\mathrm{cm})$} & \multicolumn{2}{|c|}{$\begin{array}{l}\text { Pileus thickness } \\
\text { (cm) }\end{array}$} & \multicolumn{2}{|c|}{ Stalk length $(\mathrm{cm})$} & \multicolumn{2}{|c|}{$\begin{array}{l}\text { Stalk diameter } \\
\text { (cm) }\end{array}$} & \multicolumn{2}{|c|}{$\begin{array}{l}\text { No. of effective } \\
\text { fruiting bodies }\end{array}$} \\
\hline & $1^{\text {st }}$ flush & $2^{\text {nd }}$ flush & $1^{\text {st }}$ flush & $2^{\text {nd }}$ flush & $1^{\text {st }}$ flush & $\begin{array}{c}2^{\text {nd }} \\
\text { flush }\end{array}$ & $1^{\text {st }}$ flush & $2^{\text {nd }}$ flush & $1^{\text {st }}$ flush & $\begin{array}{c}2^{\text {nd }} \\
\text { flush }\end{array}$ \\
\hline Sugarcane bagasse & $7.9 \mathrm{ab}$ & $6.52 \mathrm{~b}$ & 0.45 & $0.55 \mathrm{ab}$ & $3.22 \mathrm{c}$ & 3.69ab & 0.81 & 0.69 & $35.2 b c$ & $16.6 \mathrm{c}$ \\
\hline Coconut coir & $7.02 \mathrm{c}$ & $6.64 \mathrm{~b}$ & 0.47 & $0.49 \mathrm{~b}$ & $4.03 a b$ & $3.27 \mathrm{~b}$ & 0.85 & 0.73 & $37.8 \mathrm{~b}$ & $25.2 \mathrm{a}$ \\
\hline Saw dust & $7.47 \mathrm{bc}$ & $7.36 \mathrm{ab}$ & 0.44 & $0.53 a b$ & $4.05 \mathrm{ab}$ & $4.57 \mathrm{a}$ & 0.82 & 0.73 & $40.0 \mathrm{a}$ & $17.8 \mathrm{c}$ \\
\hline $\begin{array}{l}\text { Sugarcane bagasse } \\
\text { and coconut } \\
\text { coir(1:1) }\end{array}$ & $7.1 \mathrm{c}$ & $7.31 \mathrm{ab}$ & 0.45 & $0.55 a b$ & 4.12 a & 3.64ab & 0.78 & 0.74 & $33.4 \mathrm{c}$ & $20.4 \mathrm{~b}$ \\
\hline $\begin{array}{l}\text { Sugarcane bagasse } \\
\text { and sawdust (1:1) }\end{array}$ & 7.49 bc & $8.43 \mathrm{a}$ & 0.48 & $0.56 \mathrm{ab}$ & $3.92 \mathrm{~b}$ & 3.73ab & 0.87 & 0.68 & $33.8 \mathrm{c}$ & $17 \mathrm{c}$ \\
\hline $\begin{array}{l}\text { Sawdust and } \\
\text { coconut coir }(1: 1)\end{array}$ & 8.28 a & $7.38 \mathrm{ab}$ & 0.47 & 0.58 а & $4.04 \mathrm{ab}$ & $4.66 \mathrm{a}$ & 0.84 & 0.71 & $31.6 \mathrm{~d}$ & $27.2 \mathrm{a}$ \\
\hline CV (\%) & 4.26 & 13.63 & 7.06 & 10.61 & 4.82 & 10.99 & 9.74 & 5.55 & 11.01 & 13.0 \\
\hline $\begin{array}{l}\text { Level of } \\
\text { significance }\end{array}$ & $* *$ & $* *$ & NS & $*$ & $* *$ & $* *$ & NS & NS & $* *$ & $* *$ \\
\hline
\end{tabular}

NS = Non-significant; $* *=$ Significant at $1 \%$ level; $*=$ Significant at $5 \%$ level; 
Table 3. Yield performance of oyster mushroom on different substrates.

\begin{tabular}{|c|c|c|c|c|c|c|}
\hline \multirow[t]{2}{*}{ Substrates } & \multicolumn{2}{|c|}{ Biological yield (g) } & \multicolumn{2}{|c|}{ Economic yield (g) } & \multicolumn{2}{|c|}{ Harvest index (\%) } \\
\hline & $1^{\text {st }}$ flush & $2^{\text {nd }}$ flush & $1^{\text {st }}$ flush & $2^{\text {nd }}$ flush & $1^{\text {st }}$ flush & $2^{\text {nd }}$ flush \\
\hline Sugarcane bagasse & $92 \mathrm{~b}$ & $49.2 \mathrm{~b}$ & $89.24 \mathrm{~b}$ & $47.02 \mathrm{~b}$ & 97 & 95.56 \\
\hline Coconut coir & $131 \mathrm{a}$ & $55.60 \mathrm{ab}$ & $127.74 \mathrm{a}$ & $52.90 \mathrm{ab}$ & 97.51 & 95.14 \\
\hline Sawdust & $89 \mathrm{~b}$ & $57.32 \mathrm{ab}$ & 86.12 b & $55.0 \mathrm{ab}$ & 96.76 & 95.89 \\
\hline $\begin{array}{l}\text { Sugarcane bagasse and } \\
\text { coconut coir(1:1) }\end{array}$ & $89.1 \mathrm{~b}$ & $56.20 \mathrm{ab}$ & $85.94 \mathrm{~b}$ & $54.04 \mathrm{ab}$ & 96.45 & 96.15 \\
\hline $\begin{array}{l}\text { Sugarcane bagasse and } \\
\text { sawdust (1:1) }\end{array}$ & $98.6 \mathrm{~b}$ & $60.44 \mathrm{a}$ & $94.78 \mathrm{~b}$ & 58.18 a & 96.12 & 96.26 \\
\hline $\begin{array}{l}\text { Sawdust and coconut coir } \\
(1: 1)\end{array}$ & $97 \mathrm{~b}$ & $61.28 \mathrm{a}$ & $94.24 \mathrm{~b}$ & $57.72 \mathrm{a}$ & 97.15 & 94.19 \\
\hline CV (\%) & 6.87 & 12.60 & 6.78 & 12.75 & 1.27 & 0.95 \\
\hline Level of Significance & $* *$ & $* *$ & $* *$ & $* *$ & NS & NS \\
\hline
\end{tabular}

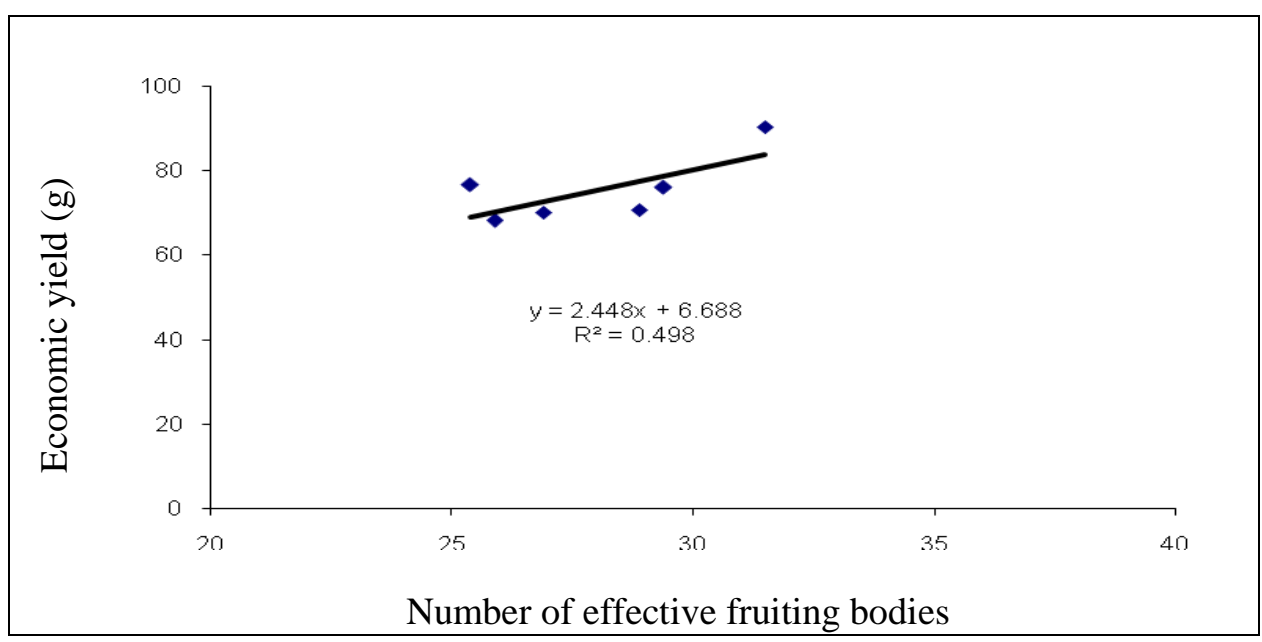

Fig. 3. Functional relationship between number of effective fruiting bodies and economic yield.

The direct linear relation is obtained between number of effective fruiting bodies and economic yield by plotting economic yield against number of effective fruiting bodies. The figure indicates that economic yield per spawn packet increased as rising the number of fruiting bodies. The figure shows that about $50 \%$ of economic yield is affected by number of effective fruiting bodies. 


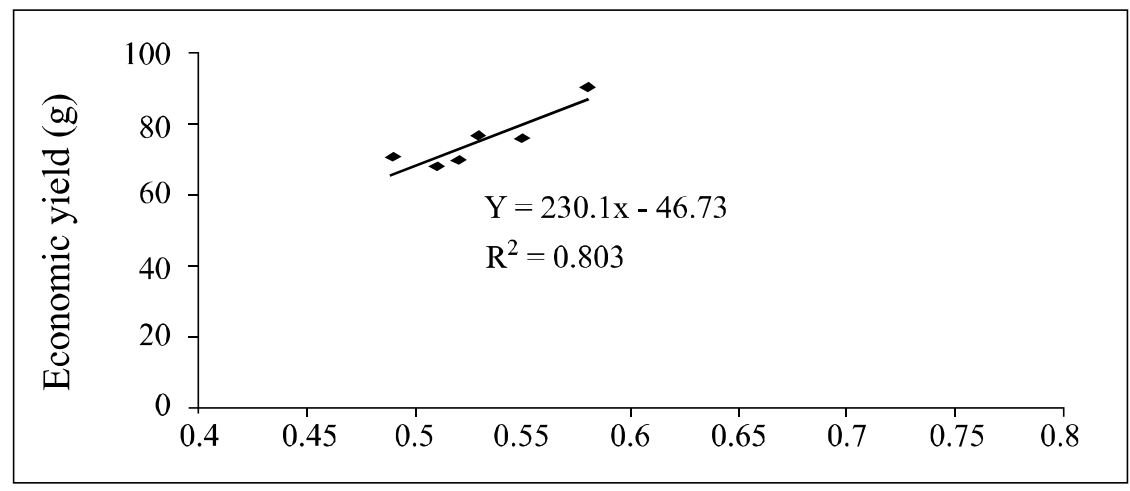

Pileus thickness (cm)

Fig. 4. Functional relationship between pileus thickness and economic yield.

The positive linear relationship between pileus thickness and economic yield is found when economic yield is plotted against pileus thickness. The relationship shows that economic yield is dependent on pileus thickness. This figure suggests that the variation of $80.3 \%$ economic yield is explained with pileus thickness.

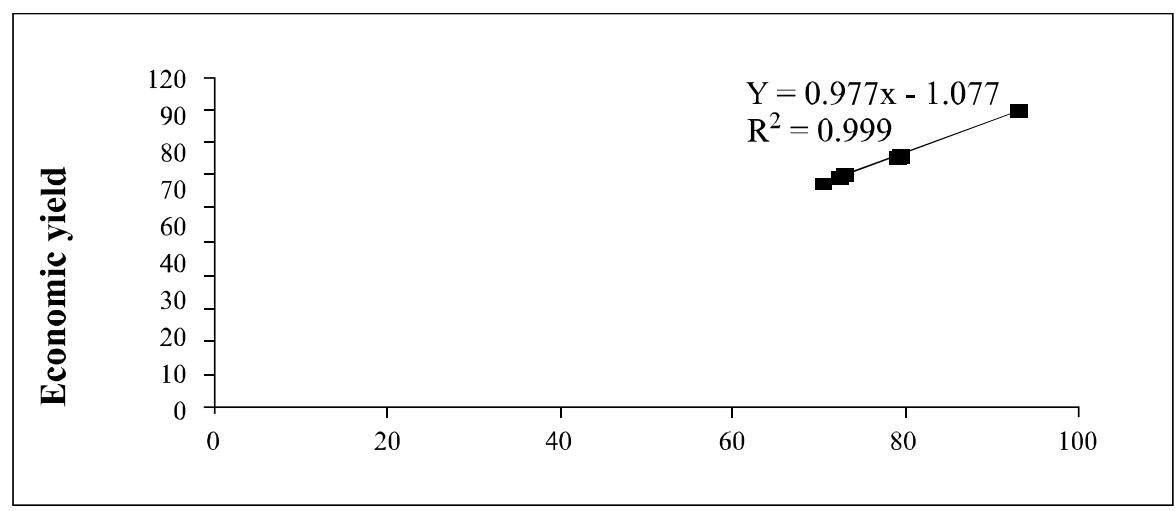

Biological yield (g)

Fig .5 Functional relationship between biological yield and economic yield.

When economic yield is regressed against biological yield then linear relation is obtained which indicates that increasing the biological yield, increasing the economic yield. The line shows that the economic yield is dependent on biological yield and over 99\% variation in economic yield may be explained by the variation of biological yield.

\section{References}

Adamovic, M., G. Grubic., I. Milenkovic., R. Jovanovic., R. Protic., L. Sretenovic and L. Stoiccvic. 1996. Biodegradation of wheat straw achieved during Pleurotus ostreatus mushroom production. J. Sc. Agril. Res. 57(3-4): 79-88. 
Bhatti, M.A., F. A. Mir and M. Siddiq. 1987. Effect of different bedding materials on relative yield of oyster mushroom in the successive flushes. Pakistan J. Agril. Res 8(3): 256-259.

Chang, S. T. and P. G. Miles. 1988. Edible Mushroom and their Cultivation. CRC Press, Inc. Boca Raton,P. florida, USA. Pp. 265-275.

Gohl, G. 1993. Tropical Feeds. Published by Food and Agriculture Organization of United Nation. Revised by Andrew speedy computer journal version-4.

Gomez, A. K. and A. A. Gomez. 1984. Statistical Procedures for Agricultural Research, 2nd Ed., John Wiley and Sons, Inc., NY. Pp .8-20.

Hadwan, H. A., M. H. Al-Jaboury and A. A. Hasan. 1997. Suitability of different substrates and amendments on the cultivation of oyster mushroom. Internatioal symposium on the development of Juncao industry. Pp. 215-221.

Kurtzman, R. H. J. and F. Zadrazil. 1982. Physiological and taxonomical consideration for cultivation of oyster mushroom, in tropical mushroom's biological nature and cultivation methods, Eds. Chinese University Press, Hong Kong. P. 299.

Patill S. S., R. M. Kadam, S. L. Shinde and S. A. Deshmukh. 2008. Effect of different substrate on productivity and proximate composition of P. Florida. Int. J. Plant Sci. 3(1): 151-153.

Poppe, J. 2000. Use of agricultural waste materials in the cultivation of mushrooms. In: L. Van Griensven ed:Proceedings 15th International Congress on Science and Cultivation of Edible Fungi, Balkema Rotterdam, 3-23.

Permana, I. G., U. Meulenter and F. Zadrazil. 2004. Cultivation of Pleurotus ostreatus and Lentinus edodes on lignocellolosic substrates for human food and animal feed production. J. Agric. Rural Dev. Tropics Subtrop. 80: 137-143.

Veena, S., S. Vijaykumar, J. H. Kulkarni and V. Savalgi. 1998. Cultivation of oyster mushroom on common weed in combination with bagasse. Karnotaka J. Agril. Sci. 11(3): 699-695.

Wang, C.W. 1982. Celluliticenzymesof Volvariella volvacea. Tropical mushroom biological nature and cultivation method.The Chinese University Press.Honkong. P172.

Yildiz, A. and A. S.Ertekin. 1996. An experimental study of mycelial development periods of some Pleurotus species. Mush Res. 5: 81-88.

Yoshida,N., T. Takahashi., T. Nagao and J. Chen. 1993. Effect of edible mushroom (Pleurotus ostreatus) cultivation on in vitro digestibility of wheat straw and sawdust substrates. J. Japanese SOC. Grassland Sci. 39(2):177-182. 